\title{
NOTES ON THE GENUS ARGOSTEMMA (RUBIACEAE) OF THE MALAY PENINSULA AND PENINSULAR THAILAND
}

\author{
KITICHATE SRIDITH \\ PSU-Herbarium, Centre for Biodiversity of Peninsular Thailand (CBiPT), \\ Department of Biology, Faculty of Science, Prince of Songkhla University, \\ Ko-Hong, Hat Yai, Songkhla, Thailand, 90112; kitichate.s@psu.ac.th
}

\section{SUMMARY}

The genus Argostemma Wall. (Rubiaceae) in the Malay Peninsula and Peninsular Thailand are discussed with regard to general morphology, distribution and ecology from studies of herbarium specimens from various herbaria together with the field surveys of the natural populations in the study area during November 2001 - December 2006.

Key words: Rubiaceae, Argostemma, Malay Peninsula, Peninsular Thailand.

\section{INTRODUCTION}

The Malay Peninsula has a common border with Peninsular Thailand and the floral elements of the southernmost part of Peninsular Thailand are included in the Malesian region by Whitmore $(1975,1984)$. Conversely, the plant elements in the northernmost part of Malaysia (Kedah State) have Thai elements. Thus many Argostemma species found in Peninsular Thailand also cross the border and occur in the Malay Peninsula and vice versa (Sridith \& Puff, 2000). Therefore, the study of the genus Argostemma in the whole of the Malay Peninsula and in the southernmost part of Peninsular Thailand is logical as being part of a natural phytogeographical unit. This comprehensive study will be an important unit, both for the phytogeography of the region and as a step towards the future attainment of a revision work of the genus Argostemma in the Malesian region.

\section{History of the genus in the region}

King \& Gamble (1903) listed 21 species of Argostemma in the Malay Peninsula. Later, Ridley (1923) reported 41 taxa of Argostemma in the Malay Peninsula. More recently, Bakhuizen van den Brink Jr. (1953) studied Argostemma for Flora Malesiana. He recorded 16 species of this genus for the whole Malesian region (including one new species from the Malay Peninsula, i.e., A. neurosepalum Bakh.f.) and proposed 5 sections of the genus, i.e., Euargostemma K. Schum., Pomangium (Reinw.) Ridl., Argostemmella (Ridl.) Bakh., Elatostemoides K. Schum. and Borragineum Bakh.f. Craib (1932) listed 33 taxa in Peninsular Thailand out of the 41 recorded as occurring in Thailand in his 'Florae Siamensis Enumeratio', most of which were considered endemic to the peninsula. Later, Sridith (1999) revised the genus for the Flora of Thailand reporting 18 species exclusively from Peninsular Thailand. 
Table 1. Names of Argostemma Wall. recorded as occurring in the Malay Peninsula (based on King \& Gamble, 1903; Ridley, 1923; Bakhuizen van den Brink Jr., 1953) and Peninsular Thailand (based on Sridith,1999). $\mathrm{x}=$ presented in any treatment, $\mathbf{X}=$ common taxa to both Malay Peninsula and Peninsular Thailand, $* \mathrm{x}=$ endemic taxa, syn. $=$ already treated as synonym.

\begin{tabular}{|c|c|c|}
\hline Taxa & Malay Peninsula & Peninsular Thailand \\
\hline A. acuminatum King & $\mathrm{x}$ & \\
\hline A. aequifolium King & $\mathrm{x}$ & \\
\hline A. albociliatum Ridl. & $\mathrm{x}$ & \\
\hline A. bicolor King & $\mathrm{x}$ & \\
\hline A. condensum Craib & & $*_{\mathrm{x}}$ \\
\hline A. curtissii King & $\mathbf{X}$ & syn. $=$ A. laeve \\
\hline A. debile Ridl. & $\mathrm{x}$ & \\
\hline A. denticulatum Ridl. & $\mathrm{x}$ & \\
\hline A. dispar Craib & & $*_{\mathrm{x}}$ \\
\hline A. diversifolium Ridl. & $\mathbf{x}$ & $\mathbf{X}$ \\
\hline A. elatostemma Hook. & $\mathbf{x}$ & $\mathbf{x}$ \\
\hline A. elongatum Ridl. & $\mathrm{x}$ & \\
\hline A. enerve Ridl. & $\mathrm{x}$ & \\
\hline A. grandiflorum Ridl. & $\mathrm{x}$ & \\
\hline A. hirsutum Ridl. & $\mathrm{x}$ & \\
\hline A. hookeri King & $\mathrm{x}$ & \\
\hline A. involucratum Hemsl. & $\mathrm{x}$ & \\
\hline A. johorense Ridl. & $\mathrm{x}$ & \\
\hline A. klossii Ridl. & $\mathrm{x}$ & \\
\hline A. kurzii C.B. Clarke & & $\mathrm{X}$ \\
\hline A. laeve Benn. subsp. setosum (E.T. Geddes) Sridith & & $*^{*} \mathrm{x}$ \\
\hline A. lanceolatum Ridl. & $\mathrm{x}$ & \\
\hline A. lobulatum Craib & & $*_{\mathrm{x}}$ \\
\hline A. lobulatum Craib var. variabile Sridith & & $*_{\mathrm{x}}$ \\
\hline A. membranaceum King & $\mathrm{x}$ & \\
\hline A. musicola Ridl. & $\mathrm{x}$ & \\
\hline A. nervosum Ridl. & $\mathrm{x}$ & \\
\hline A. neurocalyx Miq. & & $\mathrm{x}$ \\
\hline A. neurosepalum Bakh.f. & $\mathbf{X}$ & $\mathbf{x}$ \\
\hline A. nutans King & $\mathrm{x}$ & \\
\hline A. nutans King var. verticillata King \& Gamble & $\mathrm{x}$ & syn. $=A$. nutans \\
\hline A. oblongum King & $\mathrm{x}$ & \\
\hline A. ophirense Maingay ex Hook.f. & $\mathbf{x}$ & $\mathbf{x}$ \\
\hline A. perakense King & $\mathrm{x}$ & \\
\hline A. pictum Wall. & $\mathbf{X}$ & $\mathbf{X}$ \\
\hline A. pictum Wall. var. tetraphylla King \& Gamble & $\mathrm{x}$ & syn. $=$ A. pictum \\
\hline A. propinquum Ridl. & $\mathbf{x}$ & $\mathrm{x}$ \\
\hline A. puffii Sridith & $\mathrm{x}$ & $\mathrm{x}$ \\
\hline A. reptans $\mathrm{Ridl}$. & $\mathrm{x}$ & \\
\hline A. ridleyi King & $\mathrm{x}$ & \\
\hline A. rotundicalyx Sridith & & $*^{*} \mathrm{x}$ \\
\hline A. rugosum Ridl. & $\mathrm{x}$ & \\
\hline A. spinulosum C.B. Clarke ex Hook.f. & $\mathbf{X}$ & $\mathbf{X}$ \\
\hline A. stipulaceum Ridl. & $\mathbf{X}$ & $\mathbf{s y n} .=A \cdot$ propinquum \\
\hline A. subcrassum King & $\mathbf{X}$ & $\mathbf{x}$ \\
\hline A. subinaequale Benn. & $\mathrm{x}$ & \\
\hline A. tavoyanum Wall. & & $\mathrm{x}$ \\
\hline A. tenue Ridl. & $\mathrm{x}$ & \\
\hline A. trichanthum Ridl. & $\mathrm{x}$ & \\
\hline A. unifolioides King & $\mathbf{X}$ & $\mathbf{X}$ \\
\hline A. unifolium Benn. & $\mathrm{x}$ & \\
\hline A. urticifolium King & $\mathrm{x}$ & \\
\hline A. visidum King & $\mathrm{x}$ & \\
\hline A. wrayi King & $\mathrm{x}$ & \\
\hline A. yappii King & $\mathrm{x}$ & \\
\hline
\end{tabular}


Among 18 taxa in Peninsular Thailand, 7 are at present endemic (Sridith \& Puff, 2000). Of these endemic taxa, A. rotundicalyx Sridith occurs at low altitudes $(<300 \mathrm{~m})$ in Pang Nga and Surat Thani. Argostemma lobulatum var. lobulatum Craib and A. lobulatum var. variable Sridith are confined to the more northern part of the peninsula. Argostemma laeve Benn. subsp. setosum (E.T. Geddes) Sridith occurs on both the east and the west slope of the Nakhon Si Thammarat range. Argostemma condensum Craib is known only from Songkhla and Yala, where it borders Malaysia, A. puffii Sridith is endemic to one locality - Khao Toh Ngai, Petra National Park in Satun province, which also borders Malaysia and the last endemic one, A. dispar Craib is found in the southern part of Peninsular Thailand from Krabi to Pattani (Sridith \& Puff, 2000). It is highly likely that some of these taxa that have not been so far recorded from the Malay Peninsula will be found further south, e.g., A. neurocalyx Miq. This is the most widely distributed Argostemma species (Sridith \& Puff, 2000) and occurs in other parts of the Malesian region (Borneo: as revised by Bremer, 1989).

This study of collections and field surveys from the Malay Peninsula and Peninsular Thailand together should, therefore, give more accurate information of the numbers of taxa, occurrences and distributions of the genus in the study area compared to previous studies which were largely restricted by the political border. Further details concerning the characteristics confined to the taxa in the region than those in Sridith \& Puff (2001) would be also pointed out here.

\section{MATERIALS AND METHODS}

\section{Herbarium study}

Herbarium specimens from various Herbaria, i.e., AAU, BK, BKF, E, K, KEP, KLU, L, PSU and SING have been studied to get the primary data on, e.g., collector, locality, habitat, date of collection, altitude, coordinates, etc.

\section{Collecting surveys}

The surveys of natural populations of the genus Argostemma in the Malay Peninsula and Peninsular Thailand were conducted at intervals. Specimens have been processed using standard herbarium methods. Vouchers are at K, KEP, KLU, L, SING and PSU.

\section{RESULTS}

\section{The morphological characters}

\section{Vegetative characters}

\section{Growth forms}

Study of herbarium specimens and observations of the natural populations of Argostemma from the study area allow division into various growth forms: a) 'leafy stem' taxa (with several to many leaf-pairs separated by well-developed internodes) (Fig. 1a, b), e.g. A. condensum, A. yappii; b) 'pseudo-verticillate' taxa (with one pair of leaves (Fig. 1c, d), e.g. A. neurocalyx, A. pictum, A. tenue, A. unifolioides var. glabra to few leaf pairs which are in close proximity) (Fig. 1e), e.g. A. neurosepalum, A. puffii. 

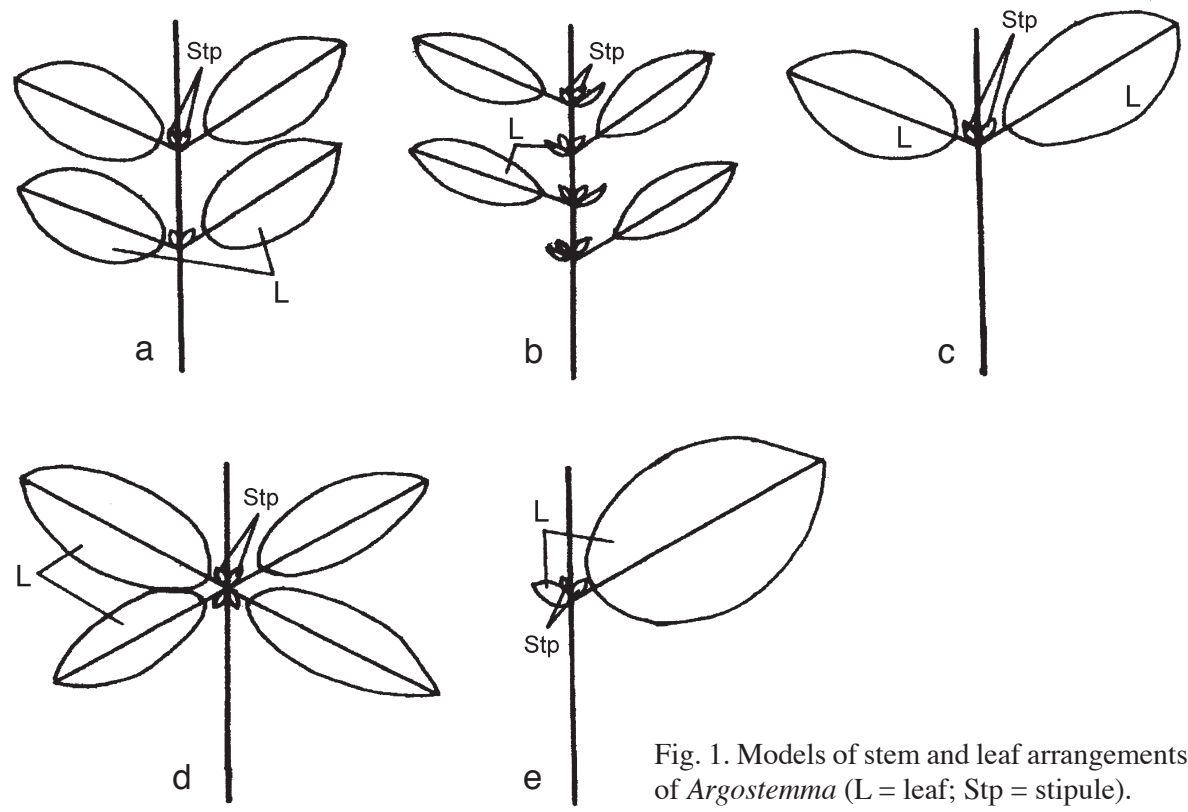

Leaves

Three types of leaf morphology and arrangement can be recognized: a) isophyllus leaves (Fig. 1a), e.g. A. boragineum; b) slightly anisophyllus leaves (Fig. 1c, e), e.g. A. puffii, A. yappii; and c) heterophyllus leaves (Fig. 1b, d), e.g. A. condensum, A. unifolioides var. glabra.

\section{Reproductive characters}

\section{Flowers}

The flowers of Argostemma from the study area are variable (Sridith \& Puff, 2001), unlike the taxa in other parts of Thailand (see also Sridith \& Puff, 2001). The different corolla types recognized are:

1. Flowers with a 'star-shaped corolla'.

1.1 Flowers with 'star-shaped corolla' with anthers coherent into a cone-like structure (sensu Sridith \& Puff, 2001) (Fig. 2).

1.2 Flowers with a 'star-shaped corolla' with free stamens (sensu Sridith \& Puff, 2001). There is only one species so far recorded in the whole genus with this type of flower: A. diversifolium (Fig. 3).

2. Flowers with a 'bell-shaped corolla' and free stamens (Fig. 4).

\section{Stamens}

There are two kinds of stamens found in the Argostemma in the study area.

1. Anthers coherent in a cone-like structure (anther cone) with the anthers opening by longitudinal slits (Fig. 5).

2. Free stamens, with the anthers opening by apical pores (Fig. 6). 

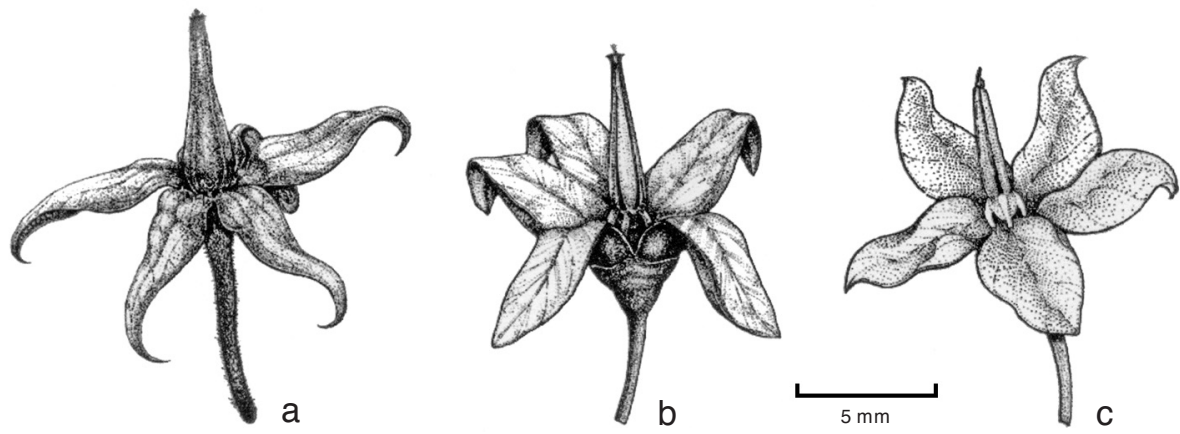

Fig. 2. Examples of flowers of some Argostemma species with a 'star-shaped corolla' and the anthers coherent in a cone-like structure. a. A. propinquum; b. A. tenue; c. A. rugosum.

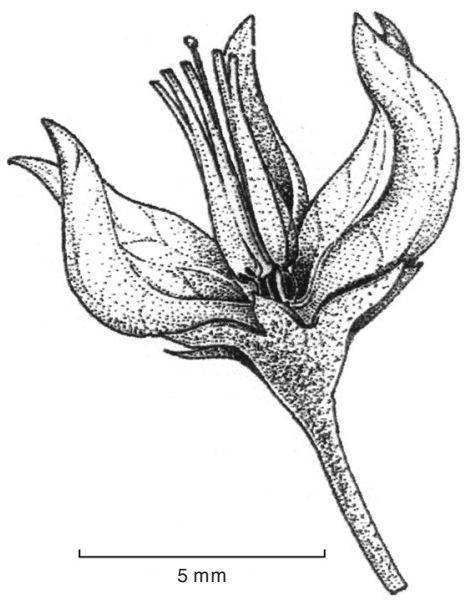

Fig. 3. Flower of Argostemma diversifolium with a 'starshaped corolla' and free stamens.
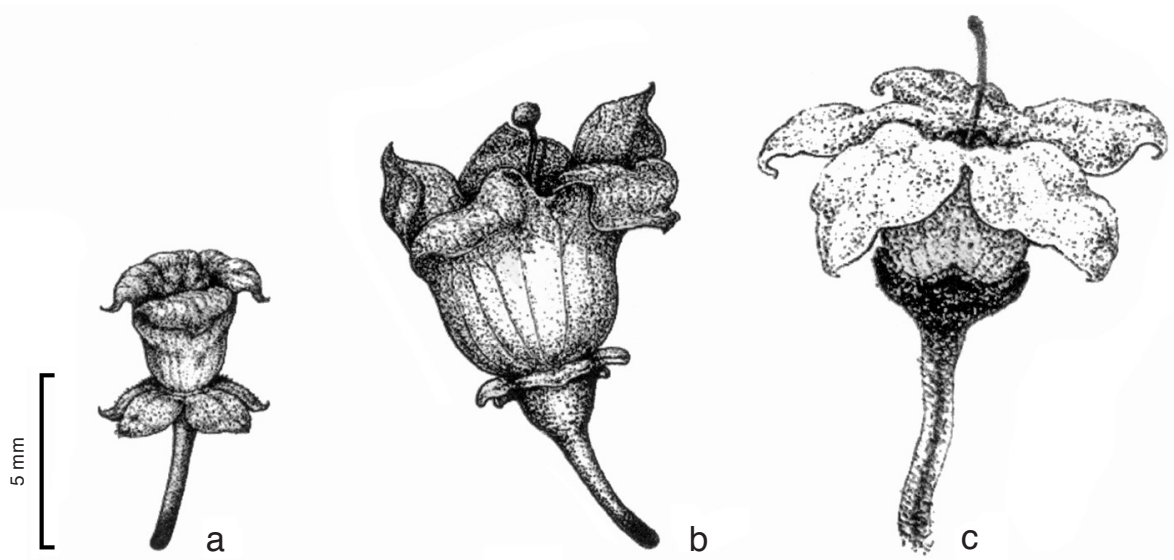

Fig. 4. Examples of flowers of some Argostemma species with 'bell-shaped corollas'. a. A. neurocalyx; b. A. puffii; c. A. lobulatum var. variabile. 


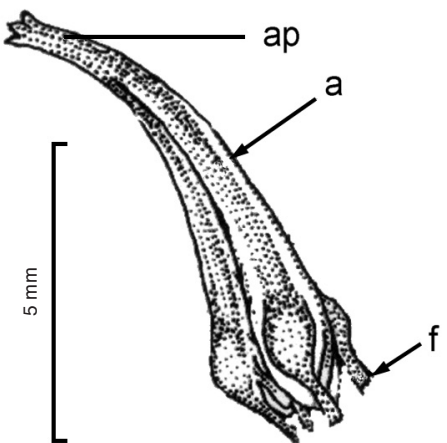

a

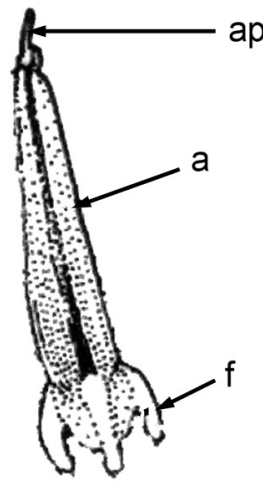

b

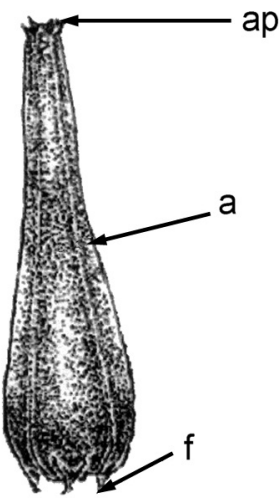

C

Fig. 5. Examples of stamens of some Argostemma species with 'anther cone' and stamens opening by longitudinal slits. a. A. involucratum; b. A. rugosum; c. A. propinquum $(\mathrm{a}=\mathrm{anther}, \mathrm{ap}=\mathrm{apical}$ appendages, $\mathrm{f}=$ filament).

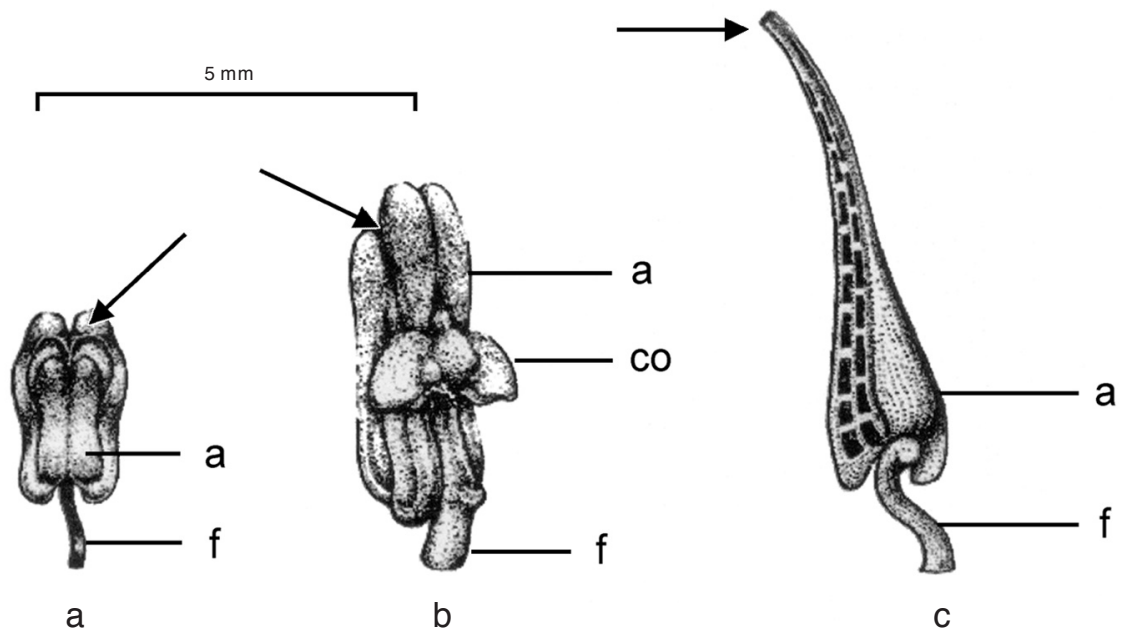

Fig. 6. Examples of some Argostemma species with free stamens and stamens opening by apical pores (arrow). a. A. neurocalyx; b. A. puffi; $\mathrm{c}$. A. diversifolium $(\mathrm{a}=$ anther, $\mathrm{co}=$ connective outgrowth, $\mathrm{f}=$ filament).

\section{Pollen}

The pollen grains of six Argostemma species have been studied so far: A. condensum, A. lobulatum var. variabile, A. pictum, A. rugosum, A. unifolioides var. glabra, A. yappii. All six have the same pollen type: prolate shape, $\mathrm{P} / \mathrm{E}$ ratio $=1.34-1.39$; tricolpate; exine microreticulate with muri and lumina smaller than $1 \mu \mathrm{m}$ to perforate (Plate 1a, b). 


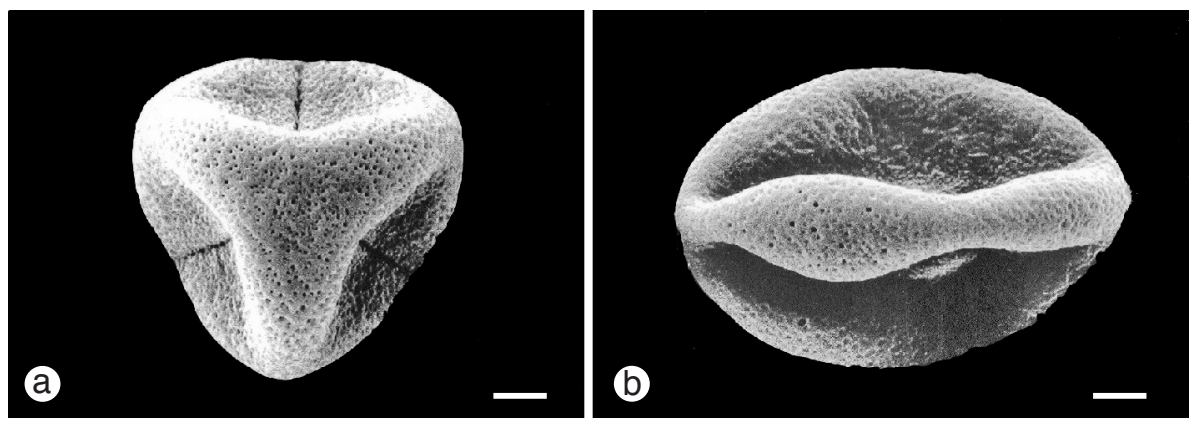

Plate 1. a, b. Electron-micrographs of the pollen grain of A. unifolioides var. glabra. - Scale bar $=2 \mu \mathrm{m}$.

\section{Stigma}

Three types of stigma have been recognized so far:

1. club shape (Fig. 7a);

2. globular shape (Fig. 7b);

3. disc shape (Fig. 7c).
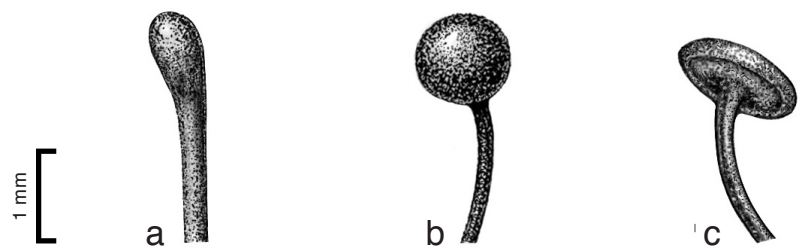

Fig. 7. Examples of stigma of some Argostemma species. a. A. lobulatum var. variabile; b. A. puffii; c. A. pictum.

\section{Fruit \& seed}

All Argostemma species have a small \pm globular fruit crowned by a persistent calyx, opening by an apical operculum. The seeds of A. lobulatum var. variabile and A. unifolioides var. glabra have been investigated. These seeds are very small (450-600 $\mu \mathrm{m}$ in both length and width) and has a thin protruding deposit of (unknown) substances on each epidermal cell of the outer seed coat (circle - Plate 2).

\section{Ecology}

All Argostemma species in the study area are only found in primary moist, evergreen forest. None of them has been collected from secondary vegetation or disturbed forest.

Two major habitat types can be identified from observations in this study:

1. Terrestrial plants - These occurred in very moist forest as ground cover both in lowland and montane situations: they are especially conspicuous in the rainy season, e.g. A. elatostemma var. obovatum, A. condensum; 


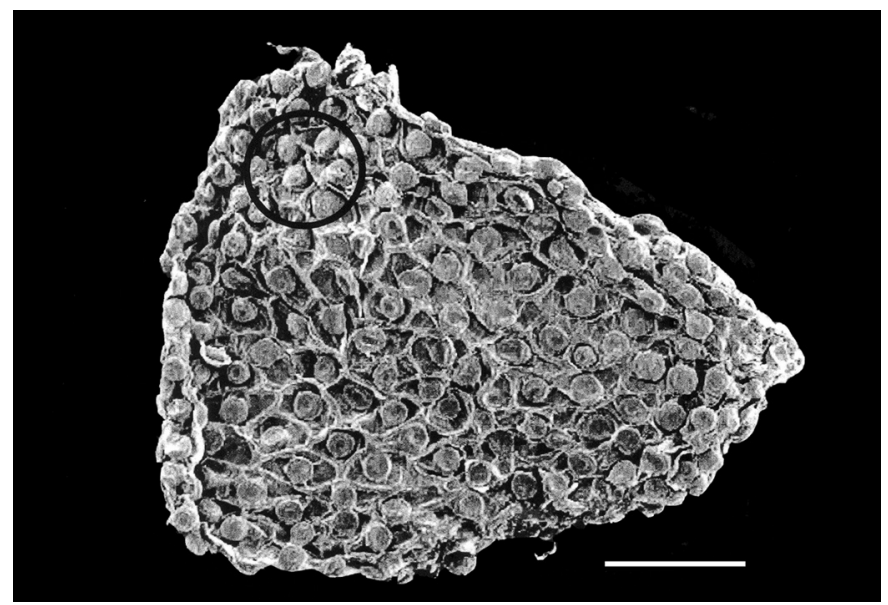

Plate 2. Electron-micrograph of the seed of A. unifolioides. - Scale bar $=100 \mu \mathrm{m}$.

2. Lithophytes - These occurred on moist rocks (often by streams) in evergreen forest in both lowland and montane situations. These taxa occur on rocks, both granite and limestone, and have tubers which lodge in the cracks. The aerial parts die in the dry season. Only the tubers survive drought periods and it is therefore difficult to find such plants in dry periods, e.g. A. diversifolium, A. puffii, A. unifolioides var. glabra.

Note - Some species can be found in both types of habitat, e.g. A. condensum, A. pictum.

\section{DISCUSSIONS AND CONCLUSIONS}

Taxa occurring in the study area

Of the recognized taxa of Argostemma in the Malay Peninsula and Peninsular Thailand, there are 9 in common to both countries: A. diversifolium, A. elatostemma, A. nerosepalum, A. ophirense, A. pictum, A. propinquum, A. spinulosum, A. subcrassum, A. unifolioides. Sridith (1999) treated A. curtisii King as a synonym of A. laeve Benn. and A. stipulaceum as a synonym of A. propinquum Ridl.

Study of herbarium specimens has so far revealed that there are two new records of species for the Malay Peninsula from Langkawi Islands (Kedah State). One of them was previously an endemic species from Peninsular Thailand, i.e., A. puffii (Kerr 21691 $(\mathrm{K})$. This is the first record of this species in the Malay Peninsula and only the second known locality after the type discovery in Satun: Khao Toh Ngai, Petra National Park. The other is of the most widely distributed Argostemma species, A. neurocalyx (M.R. Henderson 29063 (K, SING)) which has never been previously recorded from the Malay Peninsula. It is interesting to note that both these taxa have 'bell-shaped' corollas (sensu Sridith \& Puff, 2001), a corolla type previously only known in A. neurosepalum in the Malay Peninsula. Both these new records were discovered in the limestone area of Langkawi Islands. 


\section{Distribution ranges vs morphological characters}

The growth forms and morphological characters of Argostemma in the study areas are not as variable as those found in Argostemma from other parts of Thailand. The possible explanations for such phenomena may relate to the centre of origin of the genus that might be in Peninsular Malaysia seen the high number of species in comparison with other regions. Almost all taxa belong to the group with 'star-shaped' corolla with anthers in cone-like structure; isophyllus/slightly anisophyllus leaves, scattered along creeping/erect stem. These characters are considered 'primitive' in the genus. The consistent environment of the Malay Peninsula might fit such characters and therefore speciation did not end up with many variables. The only three exceptions are $A$. neurosepalum and the other two newly recorded species, i.e., A. neurocalyx and A. puffii which have 'bell-shaped' corollas. They, although in the territory of Malaysia, belong to the 'Thai type flora' not the 'Malesian flora', when the floristic boundary is considered (sensu Whitmore 1975, 1984: see Map 1). This locality should be considered the southernmost element of the range on mainland South East Asia of these two taxa. Unlike those of the Malay Peninsula, the taxa in Thailand might have experienced a gradient of environmental fluctuation owing to the distinct seasonal climate and geographical changes from the peninsular coastal plane to the mountain ranges in the north of Thailand. The secondary species explosion might have occurred, therefore taxa with more variations in morphology, especially in terms of reproductive structure e.g. flower parts (i.e. 'bell-shaped' corolla); stamens (i.e. separated anthers with poricidal dehiscence anthers) etc., are found more in Thailand than in any other areas (see also Sridith \& Puff, 2001). This 'bell-shaped' corolla, considered to be advanced, might have evolved outside the Malesian region in the areas where there is a distinct seasonal climate above the northern limit of the Malesian region. Some of them might later have dispersed down-south to the north of the Malesian region in the Malay Peninsula. Furthermore, when the floristic boundary sensu Whitmore $(1975,1984)$ is taken into account, the four 'bell-shaped' corolla taxa of Argostemma (sensu Sridith \& Puff, 2001) of the study area, i.e., A. lobulatum var. variabile, A. neurocalyx, A. neurosepalum, A. puffii rather belong to the Thai-Indochinese type of flora. The only taxon which has its southernmost distribution range in the Malesian region is A. neurosepalum (the lowest triangle on Fig. 3). It is, however, not that far from the floristic boundary which divides the Thai and Malesian types of flora sensu Whitmore $(1975,1984)$.

Conclusively speaking, the taxa with 'bell-shaped' corollas, stamens separated and anthers opening by apical pores with clusters of leaves (pseudo-verticillate taxa sensu Sridith \& Puff, 2000) and erect stem might refer to the Thai-Indochinese flora type on the one hand and the taxa with 'star-shaped' corolla, anthers fused, forming cone-like structure and opening longitudinally, leaves scattered along the stem, creeping/erect stem might refer to the Malesian flora type on the other (see Map 1).

It is also interesting to note that the taxa with 'star-shaped' corollas with long, creeping stems and distichous leaves distributed along the stem have never been found further north than the latitude of Nakhon Si Thammarat Province, Peninsular Thailand (see also Sridith \& Puff, 2000). The primary data from the present study seems to support, with very few exceptions, the (proposed) Kangar-Pattani floristic boundary line by Whitmore $(1975,1984)$. This disjunction leads to the recognition of a Thai-Indochinese type of vegetation vs a Malesian type of vegetation. The present study is only 


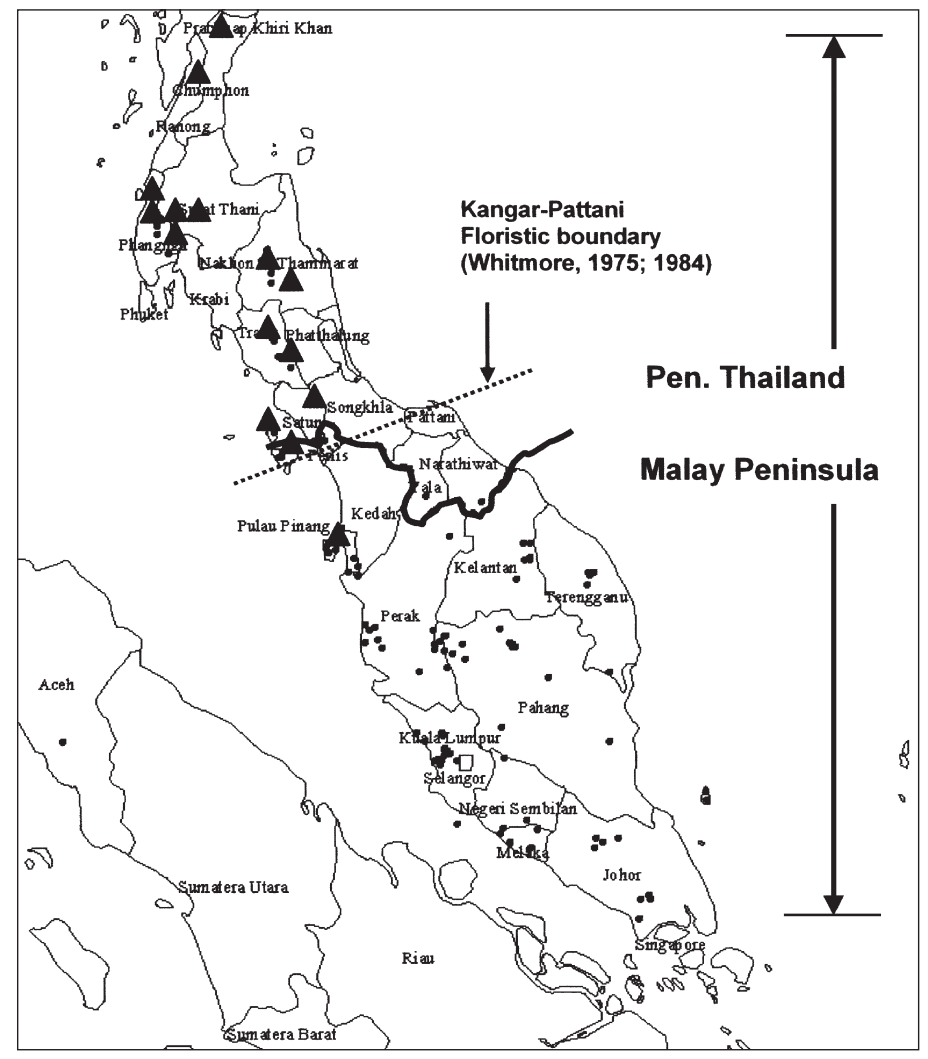

Map 1. Distribution of the genus Argostemma Wall. in the Malay Peninsula and Peninsular Thailand. - = 'star-shaped' corolla; anthers fused, forming cone-like structure and opening longitudinally; leaves scattered along stem; creeping/erect stem; $\boldsymbol{\Delta}$ = 'bell-shaped' corolla; stamens separated and anthers opening by apical pores; leaves pseudo-verticillated; erect stem.

For Peninsular Thailand, see also Sridith \& Puff (2000). The present map shows only the data recorded in the present study (October 2001 - March 2006), the Malay Peninsula, inclusively. The data concerning the localities in Thailand, focusing mainly on those taxa which occurred also in the Malay Peninsula.

a preliminary account of the taxa in the study area. Further work is needed to produce a more definitive account.

Although the genus may have no economic or medicinal importance at present, the fact that it is restricted only to undisturbed vegetation makes it valuable as an indicator genus of primary forest phytogeographic patterns. It has been never collected or found in secondary or disturbed vegetation.

In the past, the treatments of the genus Argostemma in the Malay Peninsula and Peninsular Thailand were made separately. The most recent treatments of the genus in the Malay Peninsula were done long ago (Ridley, 1923; Bakhuizen van den Brink Jr., 1953). When the author studied the genus for the Flora of Thailand (Sridith, 1999; Sridith \& Puff, 2001), few specimens from Malaysia and southernmost part of the Peninsular Thailand were included. Now a great deal of new information is allowing 
a more adequate treatment of this interesting genus in this exciting phytogeographic area which will provide new insights into distributions and relationships between the Thai flora and the Malesian region.

\section{ACKNOWLEDGEMENTS}

The author would like to express his gratitude to the ASEAN Regional Centre for Biodiversity Conservation (ARCBC) and the European Commission who sponsor the Project 'The genus Argostemma Wall. (Rubiaceae) of the Malay Peninsula and Peninsular Thailand' (Project Reference number RE-THL-2002). Thanks also go to the curator together with the 'Rubiaceous' staff of the following herbaria: AAU, E, BK, BKF, K, KEP, KLU, L and SING for their kind support. In addition, the specimens on loan from E, K, KEP, KLU, L and SING have made this research possible. I am grateful to Prof. Dr. Khun Meng Wong and his excellent staff of the Rimba Ilmu Botanic Gardens, University of Malaya, Kuala Lumpur, Malaysia for kindly arranging everything for the herbarium and field studies in Malaysia, including accommodation, working places, transportation, field assistants etc. Prof. Dr. Kai Larsen had kindly provided facilities for the study at the Herbarium, Aarhus University, Denmark. Moreover, the author is very grateful for his valuable comments on many botanical aspects. The author is most indebted to Dr. George Argent for his kind correction of English and his comments on the manuscript. Moreover, the kind hospitality of him and his wife, Prof. Sue Argent, during specimen investigation at Edinburgh is very much appreciated and unforgettable. Mr. Chukiat Laongpol from Yala provincial Environmental affair office, Department of Forestry, Yala Province, Thailand has accompanied the author for most of the field excursions both in Thailand and Malaysia. Finally, thanks also go to Prof. Dr. Christian Puff, Institute of Botany, University of Vienna who is the first person introducing the author to the genus Argostemma Wall. (Rubiaceae). All the line drawings in this study were done by Mr. Monraj Intarasiri.

\section{REFERENCES}

Bakhuizen van den Brink Jr., R.C. 1953. Florae Malesianae Praecursores V. Notes on Malaysian Rubiaceae. Blumea 7: 330-334.

Bremer, B. 1989. The genus Argostemma (Rubiaceae-Argostemmateae) in Borneo. Ann. Missouri Bot. Gard. 76: 7-49.

Craib, W.G. 1932. Florae Siamensis Enumeratio: A list of plants known from Siam: 26-36. The Bangkok Time Press, Ltd., Bangkok.

King, G. \& J. S. Gamble. 1903. Material for a Flora of the Malayan Peninsula. No. 14. J. Asiat. Soc. Bengal, Pt. 2, Nat. Hist. 72: 141-156.

Puff, C., A. Igersheim, R. Buchner \& U. Rohrhofer. 1995. The united stamens of Rubiaceae. Morphology and anatomy; their role in pollination ecology. Ann. Misssouri Bot. Gard. 82: 357-382.

Ridley, H.N. 1923. The Flora of the Malay Peninsula: 21-35. Reeve \& Co., Ltd., London.

Sridith, K. 1999. A synopsis of the genus Argostemma Wall. (Rubiaceae) in Thailand. Thai Forest Bull., Bot. 27: 86-138.

Sridith, K. \& C. Puff. 2000. Distribution of Argostemma Wall. (Rubiaceae), with special reference to Thailand and surrounding areas. Thai Forest Bull., Bot. 28: 123-138.

Sridith, K. \& C. Puff. 2001. Floral diversity in Argostemma (Rubiaceae). In: L. G. Saw, L. S. L. Chua \& K.C. Khoo (eds.), Taxonomy, the cornerstone of biodiversity. Proceedings of the Fourth International Flora Malesiana Symposium 1998: 169-180. Ampang Press Sdn. Bhd, Kuala Lumpur.

Whitmore, T.C. 1975. Tropical rain forest of the Far East: 129-138. Oxford University Press, Oxford.

Whitmore, T.C. 1984. Tropical rain forest of the Far East (revised ed.): 160-170. Clarendon Press, Oxford. 